\title{
Modeling the Effects of Human Activity on Katmai Brown Bears (Ursus arctos) through the Use of Survival Analysis
}

\author{
TOM S. SMITH ${ }^{1}$ and B. ALAN JOHNSON ${ }^{2}$
}

(Received 6 November 2000; accepted in revised form 19 December 2003)

\begin{abstract}
Brown bear-human interactions were observed in 1993, 1995, and 1997 at Kulik River in Katmai National Park and Preserve, Alaska. We analyzed these interactions using survival analysis, creating survival curves for the time that bears remained on the river in the presence, and absence, of human activity. Bear-only survival curves did not vary significantly between years $(p=0.067)$. Ninety-seven percent of bears left the river within 70 minutes of arrival in all years. Temporal patterns of bear activity were unaffected by the presence of humans as long as the bears did not share river zones with humans $(p=0.062$ to $p=0.360)$. When people and bears did not share river zones, 38.6\% (1993), 36.0\% (1995), and 37.0\% (1997) of bears remained on the river for at least 10 minutes after arrival. In contrast, when people and bears shared river zones, fewer bears remained on the river after the first 10 minutes, with $28.6 \%$ (1993), 25.0\% (1995), and 32.6\% (1997) observed in each year. We conclude that human activity displaced $26.0 \%$ (1993), 30.5\% (1995), and 12.0\% (1997) of the bears using the river, which otherwise would likely have remained longer. Over the three years of study, habituation to human activity may account for observed changes in bears' use of the river.
\end{abstract}

Key words: Alaska, bear-human conflict, brown bear, Ursus arctos, Katmai National Park, proportional hazards regression, survival analysis

RÉSUMÉ. En 1993, 1995 et 1997, des interactions ours brun-être humain ont fait l'objet d'observations à la rivière Kulik, dans la réserve de parc national Katmai, en Alaska. On a analysé ces interactions en ayant recours à l'analyse de survie, créant des courbes de survie pour la durée où les ours restaient à la rivière en présence et en l'absence d'activité humaine. Les courbes de survie pour l'ours seul ne variaient pas sensiblement d'une année à l'autre ( $p=0,067)$. Dans tous les cas, $97 \%$ des ours quittaient la rivière dans les 70 minutes suivant leur arrivée. Les schémas de comportement temporel des ours n'étaient pas affectés par la présence d'êtres humains tant que les ours ne partageaient pas les mêmes zones de rivière que les humains $(p=0,062$ à $p=0,360)$. Quand individus et ours ne partageaient pas les mêmes zones de rivière, 38,6\% (1993), 36,0 \% (1995) et 37,0 \% (1997) des ours restaient à la rivière au moins 10 minutes après leur arrivée. En revanche, quand individus et ours partageaient les zones de rivière, moins d'ours restaient à la rivière au-delà des 10 premières minutes, 28,6 \% (1993), 25,0 \% (1995) et 32,6\% (1997) ayant été observés chaque année. On conclut que l'activité humaine a délogé 26,0 \% (1993), 30,5\% (1995) et 12,0\% (1997) des ours utilisant la rivière, qui, autrement, seraient restés plus longtemps. Au cours des trois années de l'étude, il se pourrait que l'accoutumance à l'activité humaine explique les changements que l'on a observés dans l'utilisation de la rivière par les ours.

Mots clés: Alaska, conflit, ours-être humain, ours brun, Ursus arctos, parc national Katmai, régression à hasards proportionnels, analyse de survie

Traduit pour la revue Arctic par Nésida Loyer.

\section{INTRODUCTION}

In Alaska, many black bear (Ursus americanus) and brown bear $(U . \operatorname{arctos})$ populations rely heavily on spawning salmon (Oncorhynchus spp.) while preparing to hibernate. Disruption of this hyperphagic activity may have serious negative consequences for bears that cannot efficiently access these critical forage resources (Braaten and Gilbert, 1987). Hence, the concurrent use of salmon streams by humans, most often for sport fishing or bear viewing, is of concern, as it may influence the bears' individual behavior, site use, and overall population parameters. Research aimed at detecting the nature and intensity of bear response to human activity has focused on quantifying a number of parameters, including bear behavior, population parameters, and site use characteristics. Changes in bear behavior resulting from human activity may include the alteration of activity budgets, changes in bear foraging efficiency, changes in the rate and intensity of bear-human conflict, and the habituation of bears to humans in the area. Human activity may alter the total number, the age-sex composition, and the reproduction and survival of bears using the area. Bears' responses to human activity may also alter their site use characteristics, including both temporal and spatial patterns of use.

\footnotetext{
${ }^{1}$ U.S. Geological Survey, Alaska Science Center, 1011 E. Tudor Road, Anchorage, Alaska 99503, U.S.A.; tom_smith@usgs.gov

2 Argile Consulting, PO Box 4344, Kodiak, Alaska 99615, U.S.A.; a.johnson@argileconsulting.com

(C) The Arctic Institute of North America
} 


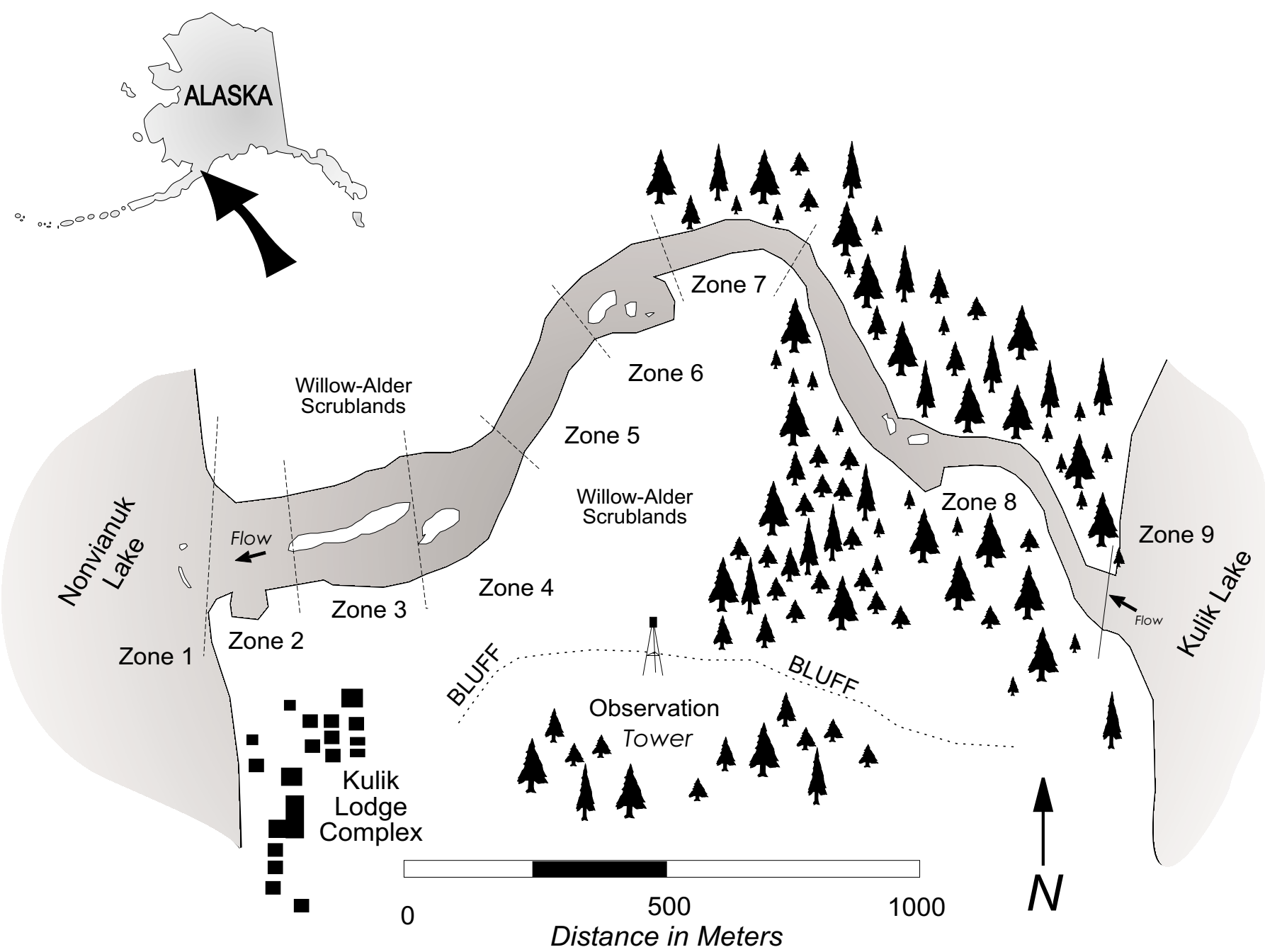

FIG. 1. Location of the Kulik River study area, Katmai National Park and Preserve, Alaska.

Warner (1987), Olson et al. (1998), Chi et al. (1998), and Smith (2002) have used a variety of analytical approaches to assess the responses of bear populations to human activity on Alaskan streams. However, no one has reported using survival analysis as a means of detecting changes in the temporal use patterns of bears in response to human activity. Pollock et al. (1989) encouraged the use of survival analysis for testing ecological hypotheses regarding the influence of covariates, such as human activity. This paper uses a previously analyzed data set (results published in Smith, 2002) to illustrate how survival analysis can add further insight into bears' responses to human activity.

Survival analysis can be used to explore data to estimate models by maximum likelihood and has been used to analyze a broad range of topics, including unemployment, marriage stability, and the efficacy of drugs (Steinberg et al., 2000). We used survival analysis to model the time to occurrence of a specified terminal event, in this case a bear's departure from the river. Unlike other analytical tools, survival analysis takes into consideration a bear's status during time intervals before the event of interest (departure from the river). A major distinguishing feature of survival analysis is the use of censored data, for example, data from the moment when an individual stops being observed until the termination of the event (in this study, the time between the end of our daily observations and the exit of bears from the river). With survival analysis it is possible to include covariates or explanatory variables, although we did not do so in this study. More complete discussions of survival analysis (Fleming and Harrington, 1991; Andersen and Keiding, 1998) will benefit those who seek additional insight into this technique. We used proportional hazards regression (Cox, 1972), a form of survival analysis, to model the length of time a bear spends on a salmon stream in the presence, and absence, of human activity, thus testing the research hypothesis that human activity decreases the time that bears spend on the river.

Brown bears congregate each fall to feed on spawning sockeye salmon (Oncorhynchus nerka) at the Kulik River, a short $(<3 \mathrm{~km})$ stream in the Katmai National Park and Preserve of southwest Alaska (Fig. 1). Lacking barriers and having a swift current, the Kulik River provides few opportunities for bears to capture live salmon. Consequently, bears are rarely seen until late August, when 
TABLE 1. Summary of 10-minute scans on the Kulik River, Katmai National Park and Preserve, Alaska. Bears are represented by "b" and humans by "h." The last column is the percentage of scans with both bears $>0$ and humans $>0$.

\begin{tabular}{cccccccc}
\hline \hline Year & Zones & Days & $\mathrm{b}=0, \mathrm{~h}>0$ & $\mathrm{~b}>0, \mathrm{~h}=0$ & $\mathrm{~b}>0, \mathrm{~h}>0$ & Total & Percent \\
\hline 1993 & 9 & 20 & 2162 & 398 & 27 & 2587 & 1.0 \\
1995 & 9 & 23 & 2597 & 1177 & 102 & 3876 \\
1997 & 7 & 18 & 305 & 5355 & 211 & 5871 & 3.6 \\
\hline
\end{tabular}

carcasses of dying salmon are abundant and easily obtained. Bears obtain fish by searching for beached, dead salmon, as well as by swimming with heads submerged in search of carcasses on the bottom.

The Kulik River has been a popular sport fishery since the 1950s, when the Kulik Lodge was established at its outlet (Bennett, 2000). Because the river is in remote wilderness, visitor access is by floatplane from nearby lodges. Kulik Lodge patrons, however, travel to the river in boats equipped with outboard motors. Although there has been human activity on the river for the past 50 years, it has quadrupled in the past decade with as many as 10 aircraft, 6 boats, 40 persons, and 70 bears sharing the river simultaneously (Smith, 2002).

A study of bear and human activity on the Kulik River was initiated, and observational data were collected from August to September in 1993, 1995, and 1997. As a result, Smith (2002) concluded that human activity influenced many aspects of bear use of the river. In an effort to extract additional insight from these data, we have used survival analysis to estimate a model of bear response to human activity. To do this, we modeled the time that bears spent on the river in the presence and absence of humans.

\section{MATERIALS AND METHODS}

Data on bear and human activity on the river were collected using scan sampling methods (Lehner, 1998). Data were collected at 10 -minute intervals, from 0800 to 2000 Alaska Standard Time, over a period of 18 to 23 days, in 1993, 1995, and 1997 (Smith, 2002). Each scan sample record included date, time, river zone, bear age and sex class, number of bears present, and number of humans present. We identified each bear group observed, which enabled us to track it from one observation to the next, thus allowing a determination of total time spent on the river. Using the starting time and ending time for each bear group, we were able to calculate the duration of its stay on the river. All records without bears present were eliminated from the analysis. Bear groups that encountered more than one group of people were not included in this analysis because it is not known how long the bear group would have remained had it not encountered additional people. Records of bears that were on the river when observations were terminated each evening were also excluded from the analysis.

We modeled the time that bears remained on the river, in the presence and absence of humans, using survival analysis and the Kaplan-Meier estimate of the survival curve (Fleming and Harrington, 1991). The Efron approximation was used to handle ties (Venables and Ripley, 1994). Significant differences $(\alpha=0.05)$ between the survival curves were tested using the $G^{\rho}$ statistic (Harrington and Fleming, 1982), with $\rho=0$, which makes this test equivalent to the Mantel-Haenszel test. We used the $\mathrm{S}$ statistical package (Becker et al., 1988) for analysis and graphics.

\section{RESULTS}

Scan sampling of the river resulted in 36936 scan observation records, 12960 in 1993, 14904 in 1995, and 9072 in 1997. The scans containing both bears and humans concurrently within the same river zone were a small percentage of the total (Table 1).

The best fit for the survival model is the exponential model. The reasonableness of the fit to the bear-only data was confirmed by approximately straight lines of the log survival curves for all three years of data (Fig. 2). Bearonly survival curves did not vary significantly between years $(p=0.067)$ except at the 70-80 minute interval $(p=$ 0.011 , Fig. 2). Ninety-seven percent of bears left the river within 70 minutes of arrival.

Only in 1997 did our observation period include any days when no humans were present at any time (days 7, 8, 9, 14, 15,17 , and 18). We compared the time that bears spent on the river when no people were encountered during an entire day to the time they spent there when people were present, but not in the zones of those bears. In this manner, we were able to see whether the mere presence of people had a riverwide effect. Except for the interval from 0 to 30 minutes ( $p=0.023$ ), the two survival curves up to 80 minutes were not significantly different ( $p=0.062$ to $p=0.360)$.

Within each year, we compared the temporal use patterns of bears on the river without humans present in their zones to those of bears that shared their zone with humans. For the models with humans present, the survival curves showed that bears departed from the river at a higher rate than if there were no humans (Fig. 3). In 1993, the survival curves were not significantly different overall $(p=0.427)$, but were significantly different $(p<0.001)$ for the first 20 minutes. In 1995, the survival curves were significantly different both overall $(p=0.032)$ and up to the first 20 minutes $(p<0.001)$. In 1997, the survival curves were significantly different both overall $(p=0.041)$ and up to the first 30 minutes $(p=0.023)$. 


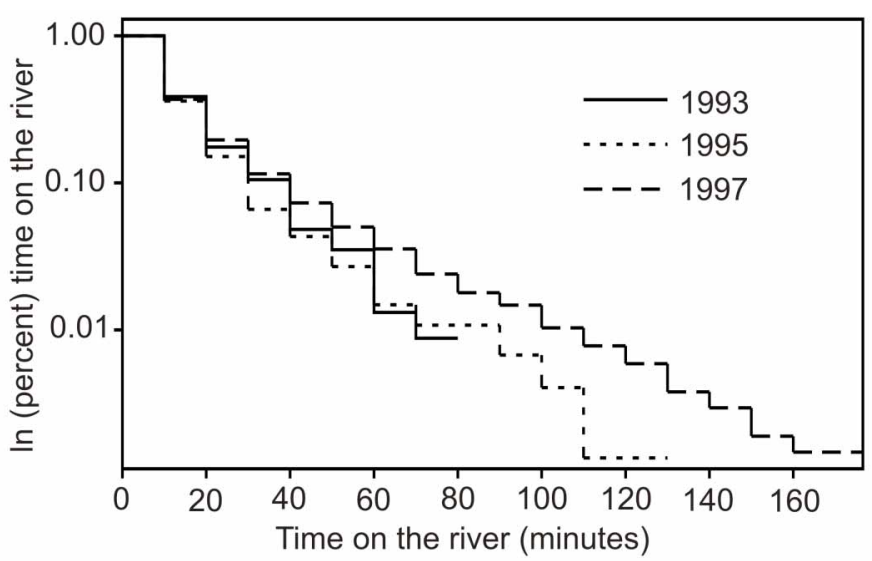

FIG. 2. Log scale survival curve to verify the assumptions of an exponential model of survival, or time on the river.

When people and bears did not share river zones, $38.6 \%$ (1993), 36.0\% (1995), and 37.0\% (1997) of bears still remained on the river after the first 10 minutes. In contrast, when people and bears shared river zones, fewer bears remained on the river after the first 10 minutes: $28.6 \%$ in $1993,25.0 \%$ in 1995 , and $32.6 \%$ in 1997 . We conclude that human activity displaced 26.0\% (1993), 30.5\% (1995), and $12.0 \%$ (1997) of the bears using the river, which otherwise would likely have remained longer.

For each successive year, the time lag from first contact with people to displacement of bears from the river increased (Fig. 3). In 1993 and 1995, more bears left the river within the first 20 minutes after arrival than in 1997. In 1997, differences occurred across the entire time interval, which may indicate habituation to human activity.

Finally, there was no significant difference between years in the time bears spent on the river in the absence of human activity ( $p=0.325$ to $p=0.583$ ).

\section{DISCUSSION}

We found no significant difference between survival curves for bears on the river (a) on days devoid of human activity (i.e., 7 days in 1997) and (b) when people were present but not sharing river zones with them. This finding suggests that when human activity (sport fishing, in this case) is at least a zone away (> $200 \mathrm{~m}$, the average length of a river zone), the temporal use patterns of bears on the river are unaffected. Neither Smith (2002) nor this work attempted to estimate the minimum distance between people and bears that must be maintained in order not to alter bear behavior. However, this finding suggests that such a minimum distance exists, and when human activity occurs beyond that distance, temporal use patterns of bears are unaltered.

Our finding that Kulik bears altered their temporal use patterns when in the presence of people is consistent with results of previous work by Olson et al. (1998), Warner (1987), and Smith (2002). Bears displaced by people may

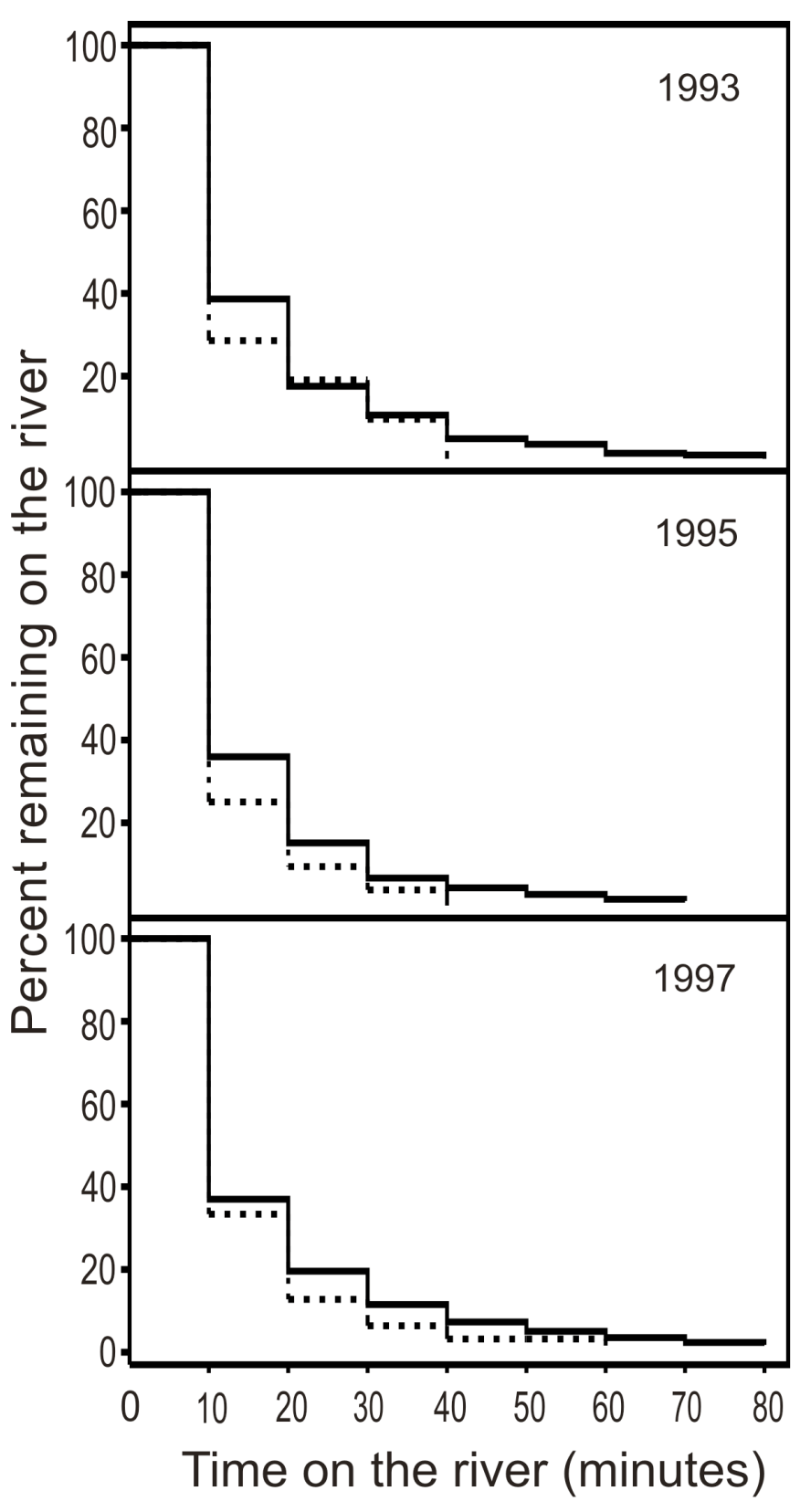

FIG. 3. Survival curves for 1993, 1995, and 1997 on the Kulik River, Katmai National Park and Preserve, Alaska. The solid line is the percentage of bears remaining on the river when humans were not present during any time. The broken line is the percentage of bears remaining on the river after an encounter with humans.

compensate by using times when people are absent (Olson et al., 1998), by fishing at night (Braaten and Gilbert, 1987), or by leaving the area entirely. By using night vision technology, T. Smith counted bears fishing at night in numbers similar to those counted during the day, a finding consistent with other reports on nocturnal fishing activity of brown bears (Klinka and Reimchen, 2002). Since human activity was present on the river for $12 \mathrm{~h}$ or more, it may be possible for bears to compensate for diurnal human disturbance by nocturnal foraging.

Survival curves for bear times on the river in the presence, and absence, of humans across the three years of 
study show a gradual delay of bear departure times. This suggests that a segment of the bear population became increasingly habituated to people, a predictable adaptation (McCullough, 1982). Although habituation may undermine the deference that bears have towards humans, bear-human incidents resulting in human injury have never been reported at Kulik (Smith, unpubl. data). Nonetheless, if human activity continues to multiply on the river, bears will find it increasingly difficult to fish without confrontation.

Previous work by Smith (2002) showed that patterns of bear use of the Kulik River were both temporally and spatially influenced by human activities. Not only did bears select those areas of the river infrequently used by people, but they also timed their use so that it did not coincide with the periods of heaviest human activity. The rarity of observations of people and bears in the same zone underscores this fact (Table 1, range 1.0-3.6\%). Additionally, Smith (2002) found that people were responsible for initiating nearly all (> 96\%) of the bear-human conflicts occurring on the river, causing nearly a quarter of the bears involved to leave the river, not to return for hours. In this work, we have further shown that the bears that interacted with people remained on the river for significantly less time than the bears using the river when people were absent, a finding consistent with other assessments of bear-human interactions on this river.

We used scan sample data collected at 10-minute intervals. More frequent sampling would have provided greater resolution regarding bear temporal use patterns, but would have been difficult to accomplish given the high level of human and bear activity occurring on the stream during peak times. Conversely, by using longer time intervals between successive scans, we would have failed increasingly to detect changes and increased the difficulty of estimating survival curves. Therefore, one should carefully consider the appropriateness of the time interval used to collect data that will be used for survival analysis.

\section{CONCLUSION}

Several studies have documented the impacts of human activity on seasonal bear aggregations at salmon streams throughout Alaska (Warner, 1987; Olson et al., 1998; Smith, 2002). The type and degree of impact may be identified by studying several metrics of bear populations. This work presents the use of survival analysis to detect changes in temporal use patterns of bears as a result of human activity.

Our analysis of survival curves for bears in the presence and absence of human activity showed that the presence of humans on a salmon stream did not alter the temporal use patterns of bears as long as river zones were not shared; that when bears and humans shared the same river zones, bears used the river significantly less; and that after four years, Kulik bears appear to have habituated to increasing human activity levels, as shown by their waning response to human activity.
A number of management implications arise from this work. Temporal use patterns of bears were unaffected by human activity as long as bears had the river zone to themselves. In other words, if human activity occurs outside a bear's personal space, the bear is unaffected. If human use continues to increase on the Kulik River, it may become necessary for managers to designate bear-only zones or human-free times of day to provide bears unimpeded access to salmon. When bears and people shared river zones, bears used the river significantly less. Although our sample size was inadequate to investigate the relative impacts of aircraft, watercraft, and anglers, this information would be very useful to managers and could be determined through the use of survival analysis. Finally, survival analysis could be used to document the habituation of a bear population to human activity.

\section{ACKNOWLEDGEMENTS}

We thank K. McCullough and two anonymous reviewers for valuable comments and guidance regarding this manuscript; S. Peterson and B. Bennett for assistance and hospitality at Kulik Lodge; B.K. Gilbert and T. Olson for their assistance; R. Potts and R. Clark of Katmai National Park and Preserve for their support. This study was jointly funded by the National Park Service and the U.S. Geological Survey.

\section{REFERENCES}

ANDERSEN, P.K., and KEIDING, N. 1998. Survival analysis: Overview. In: Armitage, P., and Colton, T., eds. Encyclopedia of biostatistics, Vol. 6. West Sussex, England: Wiley. $4452-4461$.

BECKER, R.A., CHAMBERS, J.M., and WILKS, A.R. 1988. The new S language. Pacific Grove, California: Wadsworth \& Brooks/ Cole, Publishers. 702 p.

BENNETT, B. 2000. Rods and wings: A history of the fishing lodge business in Bristol Bay, Alaska. Anchorage, Alaska: Publications Consultants.

BRAATEN, A.M., and GILBERT, B.K. 1987. Profile analysis of human-bear relationships in Katmai National Park and Preserve. Final Report for the U.S. Department of the Interior, Contract NPS CX 9700-4-0019. Logan: Utah State University.

CHI, D.K., CHESTER, D., and GILBERT, B.K. 1998. Effects of capture procedures on black bear activity at an Alaskan salmon stream. Ursus 10:563-569.

COX, D.R. 1972. Regression models and life-tables. Journal of the Royal Statistical Society B 34:187-220.

FLEMING, T.R., and HARRINGTON, D.P. 1991. Counting processes and survival analysis. New York: John Wiley. 429 p.

HARRINGTON, D.P., and FLEMING, T.R. 1982. A class of rank test procedures for censored survival data. Biometrika 69: $553-556$.

KLINKA, D.R., and REIMCHEN, T.E. 2002. Nocturnal and diurnal foraging behavior of brown bears (Ursus arctos) on a salmon 
stream in coastal British Columbia. Canadian Journal of Zoology 80:1317-1322.

LEHNER, P.N. 1998. Handbook of ethological methods. 2nd ed. Cambridge: Cambridge University Press. 672 p.

McCULLOUGH, D.R. 1982. Behavior, bears, and humans. The Wildlife Society Bulletin 10:27-33.

OLSON, T.L., GILBERT, B.K., and SQUIBB, R. 1998. Brown bear diurnal activity and human use: A comparison of two salmon streams. Ursus 10:547-555.

POLLOCK, K.H., WINTERSTEIN, S.R., BUNCK, C.M., and CURTIS, P.D. 1989. Survival analysis in telemetry studies: The staggered entry design. Journal of Wildlife Management 53: $7-15$.

SMITH, T.S. 2002. The effects of human activity on brown bear use of the Kulik River, Alaska. Ursus 13:153-163.

STEINBERG, D., PRESTON, D., CLARKSON, D., and COLLA, P. 2000. Survival analysis. Chapter 15 in SYSTAT 10 Statistics II. Chicago: SPSS Inc.

VENABLES, W.N., and RIPLEY, B.D. 1994. Modern applied statistics with S. 4th ed. New York: Springer-Verlag. 462 p.

WARNER, S.H. 1987. Visitor impacts on brown bears, Admiralty Island, Alaska. International Conference for Bear Research and Management 7:377-382. 